Arozatulo

Bawamenewi $^{1}$

\title{
PENERAPAN STRATEGI THE LEARNING CELL TERHADAP KEMAMPUAN MEMBACA ARTIKEL DALAM MEDIA CETAK
}

\begin{abstract}
Abstrak
Bahasa merupakan salah satu bentuk komunikasi yang disampaikan kepada orang lain. Pada dasarnya kemampuan bahasa itu meliputi empat jenis yakni kemampuan menyimak, kemampuan membaca, kemampuan berbicara dan kemampuan menulis. Sala satu aspek yang menjadi objek dalam penelitian ini yaitu membaca. Membaca merupakan suatu proses yang dilakukan serta digunakan oleh pembaca untuk memperoleh pesan yang hendak disampaikan oleh penulis melalui media kata-kata atau bahasa tulis. Oleh sebab itu, keterampilan di sekolah hendaknya diperhatikan para pendidik karena kegiatan tersebut bertujuan untuk mendapatkan informasi terhadap isi teks bacaan. Adapun yang menjadi tujuan dalam penelitian ini yaitu membantu para guru untuk menerapkan strategi pembelajaran, serta untuk mendeskripsikan penerapan strategi the learning cell terhadap kemampuan membaca artikel dalam media cetak dengan Penelitian Tindakan Kelas (PTK). Dengan teknik analisis data dalam penelitian ini ada dua, yakni analisis data kuantitatif dan analisis data kualitatif, dengan prosedur reduksi data yaitu menyeleksi dan mengelompokkan data berdasarkan informasi dan diorganisasikan sesuai dengan pertanyaan peneliti; paparan data, yaitu bahwa data yang sudah terorganisasi dikelompokkan atau dideskripsikan sampai bermakna dalam bentuk tabel atau grafik ataupun dinarasikan; penyimpulan, yaitu bahwa berdasarkan paparan yang telah dibuat ditarik suatu kesimpulan dalam bentuk pernyataan atau formula singkat.
\end{abstract}

Kata Kunci: Learning Cell, Kemampuan Membaca Artikel, Media Cetak

\begin{abstract}
Language is a form of communication that is conveyed to other people. Basically, there are four types of language skills, namely listening skills, reading skills, speaking skills and writing skills. One aspect that becomes the object of this research is reading. Reading is a process carried out and used by readers to get the message to be conveyed by the author through the medium of words or written language. Therefore, educators should pay attention to skills in schools because these activities aim to obtain information on the content of reading texts. The purpose of this research is to help teachers to implement learning strategies, as well as to describe the application of the learning cell strategy to the ability to read articles in print media with Classroom Action Research (CAR). There are two data analysis techniques in this study, namely quantitative data analysis and qualitative data analysis, with data reduction procedures, namely selecting and grouping data based on information and organized according to the researcher's questions; data exposure, namely that data that has been organized is grouped or described until it is meaningful in the form of tables or graphs or is narrated; conclusion, namely that based on the explanation that has been made, a conclusion can be drawn in the form of a statement or a short formula.
\end{abstract}

Keywords: Learning cell, Ability to read articles, Print media

\footnotetext{
${ }^{1}$ Pendidikan Bahasa dan Sastra Indonesia, FPBS, IKIP Gunungsitoli arozatulobawamenewi825@gmail.com
} 


\section{PENDAHULUAN}

Bahasa merupakan salah satu bentuk komunikasi yang disampaikan kepada orang lain. Pada dasarnya kemampuan bahasa itu meliputi empat jenis yakni kemampuan menyimak, kemampuan membaca, kemampuan berbicara dan kemampuan menulis. Djiwandono (2011:8) mengemukakan bahwa "kemampuan membaca menunjuk pada kemampuan untuk memahami maksud dan pikiran orang yang diungkapkan secara tertulis dalam bentuk catatan singkat, surat, artikel surat kabar, cerita pendek, novel dan lain-lain. Untuk dapat membaca suatu bacaan, seseorang harus dapat menggunakan pengetahuan yang sudah dimilikinya. Sesuai dengan pendapat Mawadah (2011:47) menyatakan bahwa "membaca adalah kegiatan berinteraksi dengan bahasa yang dikodekan ke dalam cetakan (huruf-huruf)". Selanjutnya, Mulyati (2002:2) mengemukakan bahwa "membaca adalah kegiatan merespon lambang-lambang tulis dengan menggunakan pengertian yang tepat". Dari pendapat di atas, maka peneliti menyimpulkan bahwa membaca adalah salah satu kegiatan seseorang untuk melisankan lambang-lambang tulisan yang telah ditulis oleh pengarang.

Semi (1995:192) menyatakan bawah "artikel adalah tulisan yang lengkap yang dimuat dalam surat kabar atau majalah. Kata lengkap di sini diartikan tulisan tersebut memiliki judul, pendahuluan, penyajian masalah, pembahasan dan kesimpulan”.

Berdasarkan informasi dan hasil wawancara dari guru bahasa Indonesia di SMP Negeri 2 Satu Atap Idanotae diperoleh informasi bahwa kemampuan siswa dalam membaca artikel masih kurang disebabkan karena kurangnya latihan dan motivasi siswa dalam proses belajar membaca, kemampuan menemukan ide pokok dalam bacaan masih kurang, serta kemampuan menemukan masalah dalam sebuah teks artikel masih kurang, proses pembelajaran yang berlangsung masih satu arah, cara guru mengajar membosankan dan kurang menarik, guru belum menggunakan strategi pembelajaran secara maksimal, motivasi belajar siswa masih kurang, dan hasil belajar siswa masih kurang.

Guru adalah salah satu komponen yang sangat besar pengaruhnya terhadap peningkatan hasil belajar siswa, karena gurulah yang berhadapan langsung dengan siswa dalam proses pembelajaran. Sesuai dengan pendapat Djiwandono (2007:8) mengemukakan bahwa "dalam pelaksanaan pembelajaran sesungguhnya pengaruh antara komponen penyelenggara pembelajaran itu bahkan tidak sekedar bersifat satu arah dari komponen sebelumnya ke arah komponen berikutnya, pengaruh itu tidak saja berasal dari komponen tujuan sebagai landasan yang menentukan bagaimana komponen kegiatan pembelajaran diselenggarakan tetapi komponen itu dapat bersifat timbal balik. Searah dengan pendapat Wena (2011:2) mengemukakan bahwa "guru sebagai komponen penting dari tenaga pendidikan, memiliki tugas untuk melaksanakan proses pembelajaran di kelas".

Oleh karena itu, untuk mengatasi hal tersebut di atas, maka salah satu upaya yang dapat dilakukan oleh guru adalah dengan menerapkan salah satu strategi pembelajaran the learning cell. Zaini (2010:86) menyatakan bahwa "strategi pembelajaran the learning cell adalah suatu bentuk belajar kooperatif dalam bentuk berpasangan, di mana pesera didik bertanya dan menjawab pertanyaan secara bergantian pada materi bacaan yang sama". 


\section{Tinjauan Teori}

\section{Menbaca}

Membaca merupakan suatu proses yang dilakukan serta digunakan oleh pembaca untuk memperoleh pesan yang hendak disampaikan oleh penulis melalui media katakata atau bahasa tulis. Oleh sebab itu, keterampilan di sekolah hendaknya diperhatikan para pendidik karena kegiatan tersebut bertujuan untuk mendapatkan informasi terhadap isi teks bacaan. Jika hal ini tidak terpenuhi, maka pesan yang tersurat maupun yang tersirat tidak akan dipahami dan proses membaca tidak terlaksana dengan baik. Membaca salah satu jenis kemampuan berbahasa lisan yang bersifat reseptif artinya dengan kegiatan membaca seseorang akan dapat memperoleh informasi, ilmu pengetahuan, dan pengalaman-pengalaman baru. Semua yang diperoleh melalui bacaan akan memungkinkan orang tersebut mampu memperluas daya pikirnya, mempertajam pandangannya, dan memperluas wawasannya.

Soedarso (2010:4) menyatakan membaca adalah aktivitas yang kompleks dengan menggerakkan sejumlah besar tindakan yang terpisah-pisah meliputi orang yang mendengarkan pengertian dan khayalan, mengamati dan mengingat-ingat. Nugraha dan Husnul (2011:2) mengatakan membaca adalah suatu proses yang dilakukan oleh seseorang untuk memperoleh pesan atau pengetahuan yang ditulis melalui kata-kata dalam bentuk tulisan. Searah dengan pendapat Tarigan (2005:7) menyatakan membaca adalah suatu proses yang dilakukan dan dipergunakan oleh pembaca untuk memperoleh pesan, yang hendak disampaikan oleh penulis melalui media kata-kata atau bahasa tulis.

\section{Media Cetak}

Media merupakan alat bantu proses belajar mengajar. Segala sesuatu yang dapat dipergunakan untuk merangsang pikiran, perasaan, perhatian dan kemampuan atau keterampilan peserta didik sehingga dapat mendorong terjadinya proses belajar. Searah dengan pendapat Kustandi dan Sutjipto (2011:8) menyatakan secara harafiah media dalam proses belajar mengajar cenderung diartikan sebagai alat grafis, fotografis atau elektronis untuk menangkap, memproses dan menyusun kembali informasi visual atau verbal. Searah dengan pendapat Sadiaman, dkk (2010:6) menyatakan media berasal dari bahasa Latin yaitu Medius yang secara harafiah perantara atau pengantar agar pesan dari pengirim dapat diterima penerima pesan media sebagai sarana yang efektif dalam menyampaikan pelajaran. Dari pendapat tersebut, dapat disimpulkan bahwa media pembelajaran adalah segala sesuatu yang dapat menyalurkan pesan, dapat merangsang fikiran, perasaan, dan kemauan peserta didik sehingga dapat mendorong terciptanya proses belajar pada diri peserta didik.

Media berfungsi untuk tujuan instruksi di mana informasi yang terdapat dalam media itu harus melibatkan siswa baik dalam benak atau mental maupun dalam bentuk aktivitas yang nyata sehingga pembelajaran dapat terjadi. Materi harus dirancang secara lebih sistematis dan psikologis dilihat dari segi prinsip-prinsip belajar agar dapat menyiapkan instruksi yang efektif. Di samping menyenangkan, media pembelajaran harus dapat memberikan pengalaman yang menyenangkan dan memenuhi kebutuhan peserta didik.

\section{Strategi The Learning Cell}

Strategi pembelajaran merupakan suatu serangkaian rencana kegiatan yang termasuk didalamnya penggunaan metode dan pemanfaatan berbagai sumber daya 
atau kekuatan dalam suatu pembelajaran. Sudjana (2001:37) mengemukakan strategi pembelajaran dapat ditinjau berdasarkan pengertian secara sempit dan pengertian secara luas. Secara sempit, strategi pembelajaran dapat diartikan sebagai cara yang digunakan untuk mencapai tujuan pembelajaran. Sedangkan secara luas, strategi pembelajaran dapat diberi arti sebagai penetapan semua aspek yang berkaitan dengan mencapaian tujuan pembelajaran, termasuk di dalamnya adalah perencanaan, pelaksanaan, dan penilaian terhadap proses, hasil dan pengaruh kegiatan pembelajaran. Dari pengertian tersebut, peneliti menyimpulkan bahwa strategi pembelajaran adalah suatu rencana tindakan (rangkaian kegiatan) yang termasuk juga penggunaan metode dan pemanfaatan berbagai sumber dalam pembelajaran di sekolah demi mencapai tujuan pembelajaran.

Salah satu strategi pembelajaran yang digunakan dalam penelitian ini adalah strategi the learning cell. Menurut Istarani (2011:228) mengemukakan bahwa strategi sel belajar pertama kali dikembangkan oleh Goldschmid dari Swiss Federal Institute of Technology di Lausanne (Goldschmid, 1971). Learning Cell membentuk pada suatu belajar kooperatif dalam bentuk berpasangan, dimana siswa bertanya dan menjawab pertanyaan secara bergantian berdasarkan materi yang sama. Salah satu dari beberapa system terbaik untuk membantu pasangan peserta didik belajar dengan efektif adalah learning cell.

Istarani (2011:228) mengemukakan beberapa langkah-langkah strategi the learning cell yaitu:

a. Sebagai persiapan, siswa diberi tugas membaca suatu bacaan kemudian menulis pertanyaan yang berhubungan dengan masalah pokok yang muncul dari bacaan atau materi terkait lainnya.

b. Pada awal pertemuan, siswa ditunjuk untuk berpasangan dengan mencari kawan yang disenangi. Siswa A memulai dengan membacakan pertanyaan pertama dan dijawab oleh siswa B.

c. Setelah mendapatkan jawaban dan mungkin telah dilakukan koreksi atau diberi tambahan informasi, giliran siswa B mengajukan pertanyaan yang harus dijawab oleh siswa A.

d. Jika siswa A selesai mengajukan satu pertanyaan kemudian dijawab oleh siswa B, ganti B yang bertanya, dan begitu seterusnya.

e. Selama berlangsung tanya jawab, guru bergerak dari pasangan ke pasangan yang lain sambil memberi masukan atau penjelasan dengan bertanya atau menjawab pertanyaan.

\section{METODE}

Penelitian Tindakan Kelas (PTK) merupakan suatu bentuk penelitian yang bersifat reflektif dengan melakukan tindakan-tindakan tertentu untuk memperbaiki dan meningkatkan kualitas pembelajaran di kelas secara lebih berkualitas sehingga siswa dapat memperoleh hasil belajar yang lebih baik. Sukaryana (2006:9) menyatakan bahwa penelitian tindakan kelas merupakan salah satu upaya guru atau praktisi dalam bentuk berbagai kegiatan yang dilakukan untuk memperbaiki keadaan yang kurang memuaskan dan untuk meningkatkan mutu pelajaran di kelas. Searah dengan pendapat Suranto, dkk, (2010:10) menyatakan bahwa PTK adalah bentuk penelitian yang dilaksanakan oleh guru untuk memecahkan masalah yang dihadapi dalam melaksanakan tugas pokoknya yaitu mengelolah pelaksanaan kegiatan belajar mengajar. Sesuai dengan jenis penelitian ini yaitu PTK, maka penelitian ini memiliki beberapa tahapan pelaksanaan yaitu 
perencanaan, tindakan, observasi, dan refleksi. Pelaksanaan tindakan dalam penelitian ini direncanakan dua siklus. Adapun tahapan pelaksanaan siklus ini yaitu: tahap perencanaan; tahap pelaksanaan tindakan, tahap observasi, tahap refleksi

Teknik analisis data dalam penelitian ini ada dua, yakni analisis data kuantitatif dan analisis data kualitatif.

1. Analisis data kuantitatif

2. Analisis data kualitatif

a. Reduksi data, yaitu menyeleksi dan mengelompokkan data berdasarkan informasi dan diorganisasikan sesuai dengan pertanyaan peneliti.

b. Paparan data, yaitu bahwa data yang sudah terorganisasi dikelompokkan atau dideskripsikan sampai bermakna dalam bentuk tabel atau grafik ataupun dinarasikan.

c. Penyimpulan, yaitu bahwa berdasarkan paparan yang telah dibuat ditarik suatu kesimpulan dalam bentuk pernyataan atau formula singkat.

\section{HASIL DAN PEMBAHASAN}

Penelitian tindakan kelas ini dilaksanakan di SD Negeri No. 078467 Buhawa Hilimbowo Kabupaten Nias Selatan. Subjek penelitian adalah siswa kelas V yang berjumlah 44 orang. Sebelum penelitian dilakukan, terlebih dahulu peneliti konsultasi kepada kepala sekolah SD Negeri No. 078467 Buhawa Hilimbowo dan kepada guru mata pelajaran bahasa Indonesia yang mengajar di kelas V. Pelaksanaan penelitian ini mengikuti alur atau tahapan yaitu perencanaan, tindakan, observasi, dan refleksi.

Penelitian ini dilaksanakan sebanyak dua kali pertemuan dan satu kali pertemuan pemberian tes hasil belajar setiap siklus. Pelaksanaan penelitian ini disesuaikan dengan jadwal pada mata pelajaran di kelas V. Pelaksanaan penelitian dilakukan secara kolaborasi yaitu dengan menggunakan jasa pengamat lain yakni guru mata pelajaran Pendidikan bahasa Indonesia di kelas $\mathrm{V}$ yang membantu dalam pelaksanaan observasi selama penelitian berlangsung, sehingga kegiatan penelitian ini dapat terlaksana dengan baik. Kegiatan penelitian dilaksanakan bertepatan pada jam pembelajaran bahasa Indonesia sehingga tidak mengganggu proses pelaksanaan pembelajaran yang lain dan juga peneliti sekaligus sebagai praktisi tidak perlu meninggalkan kelas selama proses pembelajaran berlangsung.

Penelitian tindakan kelas ini dilakukan dengan 4 tahapan yaitu: perencanaan, tindakan, observasi, dan refleksi yang disajikan dalam dua siklus sebagai berikut:

\section{Siklus I}

1. Pembelajaran pada Siklus I

Pada pembelajaran siklus I dengan materi membaca artikel dilakukan beberapa tahap mulai dari tahap perencanaan yaitu menyusun rencana pelaksanaan pembelajaran dengan menerapkan strategi the learning cell, menetapkan waktu pelaksanaanya, menyiapkan lembar observasi, menyiapkan naskah tes hasil belajar siswa. Setelah tahap perencanaan maka tahap berikutnya berupa tindakan di mana seluruh proses kegiatan belajar mengajar dengan menerapkan strategi the learning cell dilaksanakan. Tahap berikutnya adalah observasi, di mana selama proses pembelajaran berlangsung guru mata pelajaran bahasa Indonesia bertindak sebagai pengamat dan mengisi lembaran observasi yang telah disediakan, dan setelah itu dilakukan refleksi.

2. Hasil Observasi untuk Guru pada Siklus I 
Hasil obsevasi guru pada siklus I adalah pada pertemuan pertama 51,92\% sehingga digolongkan kurang sedangkan pada pertemuan kedua 60,93\% digolongkan cukup. Jadi, rata-rata persentase hasil pengamatan untuk guru selama dua kali pertemuan adalah 56,42\% maka hasil observasi guru atau peneliti dalam proses pembelajaran masih digolongkan kurang. Pada pembelajaran ini ada beberapa indikator yang masih belum dicapai klasifikasi baik, oleh karena itu perlu dilakukan perbaikan pada siklus berikutnya.

3. Hasil Observasi Siswa pada Siklus I

Hasil observasi untuk siswa pada siklus I pertemuan pertama dengan total nilai sebesar 225 sehinga persentase pengamatan sebesar 56,81\% digolongkan kurang dan pertemuan kedua dengan jumlah 437 Dengan demikian persentase hasil observasi siswa selama dua kali pertemuan pada siklus pertama adalah $61,51 \%$ tergolong kurang. Pada pertemuan ini aktivitas siswa masih belum mencapai target yang diharapkan sehingga perlu ditingkatkan pada siklus II.

4. Hasil Belajar pada Siklus I

Hasil belajar siswa diperoleh dengan menggunakan tes membaca artikel dari media cetak dengan menggunakan langkah-langkah strategi pembelajaran the learning cell. Berdasarkan perolehan siswa pada tes hasil belajar siklus I, jumlah siswa yang dinyatakan tuntas adalah 21 orang dengan pesentase adalah 47,72\% dan siswa yang tidak tuntas adalah 23 orang dengan persentase $52,27 \%$.

5. Refleksi siklus I

Sebagai refleksi pada siklus I adalah mengungkap kembali hasil yang telah dicapai berdasarkan temuan penelitian dan mengungkap kelemahan-kelemahan yang perlu ditingkatkan pada siklus berikutnya. Sebagai refleksi pada siklus ini adalah:

a) Kelemahan-kelemahan yang diketahui selama proses pembelajaran siklus I adalah guru masih kurang tepat menyampaikan strategi pembelajaran disebabkan karena suasana kelas yang kurang konduktif sehingga proses pembelajaran tidak dapat terkontrol, kurangnya guru menjelaskan karakteristik artikel kepada siswa sehingga siswa binggung terhadap pembealajaran, kurang adanya umpan balik kepada siswa dalam bentuk tanya jawab sehingga guru mendominasi pembelajaran di kelas.

b) Pada hasil observasi siswa terlihat adanya siswa yang kurang antusias dalam mengikuti pembelajaran membaca artikel dari media cetak sehingga siswa kurang menanyakan hal-hal yang belum jelas terhadap pembelajaran disebab karena pengetahuan dan pemahaman siswa terhadap teks bacaan masih kurang. Dari hasil tersebut di atas, belum mencapai KKM di SD Negeri No. 078467 Buhawa Hilimbowo maka, perlu dilanjutkan pada siklus II.

\section{Siklus II}

1. Pembelajaran pada Siklus II

Pembelajaran siklus II dua kali pertemuan dengan menerapkan strategi pembelajaran the learning cell. Pelaksanaan penelitian ini dilakukan berdasarkan pada waktu yang telah ditetapkan sebelumnya. Selama proses pembelajaran berlangsung, guru mata pelajaran Bahasa Indonesia hadir di ruang kelas dan bertindak sebagai pengamat yaitu dengan melakukan pengamatan terhadap proses pembelajaran yang dilakukan oleh peneliti dan juga aktivitas yang dilakukan siswa selama pembelajaran berlangsung sesuai dengan indikator yang telah disediakan sebelumnya pada lembar observasi. 
2. Hasil Observasi untuk Guru pada Siklus II

Hasil obsevasi guru pada siklus II mengalami peningkatan bila dibandingkan pada siklus I di mana persentase pengamatan pada pertemuan pertama sebesar $84,61 \%$ tergolong gagal dan pada pertemuan kedua meningkat menjadi $90,62 \%$ tergolong baik sekali. Jadi, rata-rata persentase hasil pengamatan untuk guru selama dua kali pertemuan adalah $87,61 \%$ tergolong baik sekali.

3. Hasil Observasi Siswa pada Siklus II

Hasil observasi untuk siswa pada siklus II pertemuan pertama dengan total nilai sebesar 273 sehinga persentase pengamatan sebesar 68,93\% digolongkan cukup dan pertemuan kedua dengan jumlah 568, sedangkan persentase pengamatan sebesar 86,06\% tergolong baik sekali. Dengan demikian persentase hasil observasi siswa selama dua kali pertemuan pada siklus II adalah 77,49\% tergolong baik. Pada pertemuan ini aktivitas siswa telah mencapai target yang telah diharapkan tanpa melanjutkan pada siklus berikutnya.

4. Hasil Belajar pada Siklus II

Hasil belajar siswa diperoleh dengan menggunakan tes membaca artikel dengan menggunakan langkah-langkah strategi pembelajaran the learning cell. Berdasarkan perolehan siswa pada tes hasil belajar siklus II, jumlah siswa yang dinyatakan tuntas adalah 44 orang dengan pesentase adalah $100 \%$.

5. Refleksi siklus II. Berdasarkan hasil yang diperoleh baik pada lembar observasi siswa maupun guru telah memenuhi tingkat klasifikasi penilaian sehingga refleksi pada pembelajaran siklus kedua tidak perlu diadakan karena telah sesuai dengan yang diharapkan.

\section{SIMPULAN}

Berdasarkan hasil temuan penelitian dan hasil analisis pada Bab sebelumnya maka dapat disimpulkan bahwa:

1) Membaca adalah suatu proses yang dilakukan serta dipergunakan oleh pembaca untuk memperoleh pesan yang hendak disampaikan penulis melalui kata-kata dalam bahasa tulis.

2) Artikel adalah segala jenis tulisan atau karangan yang terbit atau akan diterbitkan di surat kabar atau buku dengan tujuan untuk menyampaikan gagasan dan fakta yang dapat meyakinkan, mendidik, dan menghibur orang lain.

3) Strategi pembelajaran the learning cell adalah suatu bentuk belajar kooperatif dalam bentuk berpasangan, di mana pesera didik bertanya dan menjawab pertanyaan secara bergantian pada materi bacaan yang sama.

4) Berdasarkan hasil evaluasi pada tes membaca artikel dalam media cetak nilai ratarata siklus I adalah 68,97 dan siklus II adalah 85,56.

5) Nilai yang diperoleh siswa pada siklus I terhadap hasil tes membaca artikel dalam media cetak adalah nilai terendah adalah 56 dan nilai tertinggi adalah 81 .

6) Nilai yang diperoleh siswa pada siklus II terhadap hasil tes membaca artikel dalam media cetak adalah nilai terendah adalah 76 dan nilai tertinggi adalah 94.

7) Hasil pengamatan pada lembar observasi guru pada siklus I adalah 56,42 dan siklus II 87,61 dengan persentase 30,99\%.

8) Hasil pengamatan pada lembar observasi siswa yang aktif pada siklus I adalah 61,51 dan siklus kedua adalah 77,49 dengan persentase $15,98 \%$ sedangkan siswa yang tidak aktif pada siklus I adalah 38,49 dan siklus II 77,49 dengan persentase 15,98. 


\section{DAFTAR PUSTAKA}

Bawamenewi, Arozatulo. (2019). Pengembangan Bahan Ajar Memprafrasekan Puisi “Aku” Berdasarkan Model Pembelajaran Problem Based Learning (PBL). Jurnal Review Pendidikan dan Pengajaran, 2(2), 310-323.

Bawamenewi, Arozatulo. (2020). Analisis Tindak Tutur Bahasa Nias Sebuah Kajian Pragmatik. Jurnal Review Pendidikan dan Pengajaran, 3(2), 200-208. https://journal.universitaspahlawan.ac.id/index.php/jrpp/article/view/1217/961

Djamarah, Syaiful Bahri. (2010). Guru dan Anak Didik dalam Interaksi Edukatif. Jakarta: Rineka Cipta.

Djiwandano, Soenardi. (2011). Tes Bahasa Pegangan Bagi Pengajar Bahasa. Malang: IKAPI.

Kamaroesid, Herry. (2009). Menulis Karya Ilmiah untuk Guru. Jakarta: Gaung Persada.

Mahayati. (2009). Membaca Modalmu untuk Masa Depan. Jakarta Selatan: Buana Cipta Pustaka.

Mawadah, Ade Husnul. (2011). Panduan Pendidikan: Strategi Belajar Mengajar Bahasa dan Sastra Indonesia. Jakarta Timur: PT. Multazam Mulia Utama.

Mulyati, Yeni. (2002). Pendidikan Bahasa dan Sastra Indonesia di Kelas Tinggi. Jakarta: Universitas Terbuka.

Rasyid, Mansur. (2009). Penilaian Hasil Belajar. Bandung: CV. Wacana Prima.

Sadiaman, Arif S, dkk. (2010). Media Pendidikan, Pengertian, Pengembangan dan Pemanfaatanya. Jakarta: PT. Raja Grafindo Persada.

Sanaki, Hujair AH. (2011). Media Pembelajaran. Yogyakarta: Kaukaba.

Semi, Antar. 1995. Teknik Penulisan Berita, Features, adan Artikel. Bandung: Mugantara.

Soedarso. (2005). Sistem Membaca Cepat dan Efektif. Jakarta: PT. Gramedia Pustaka Umar.

Sudjana. (2001). Metode dan Teknik Pembelajaran Parsitipasif. Bandung: Falah Production.

Sukaryana, dkk. (2006). Penelitian Tindakan Kelas (PTK). Malang: Univerisitas Malang.

Suranto, dkk. (2008). Manajemen Penelitian Tindakan Kelas. Jakarta: Insan Cendekia.

Sutjipto Bambang, Kustandi Cecep. (2011). Media Pembelajaran Manual dan Digital. Jakarta: Ghalia Indonesia.

Tampubolan, DP. (2002). Kemampuan Membaca Teknik Membaca Efektif dan Efesien. Bandung: Angkasa.

Tarigan, Henry Guntur. (2005). Membaca Sebagai Suatu Keterampilan Berbaha. Bandung: Angkasa.

Wena, Made. (2008). Strategi Pembelajaran Inovatif Kontemporer Suatu Tinjauan Konseptual Operasional. Jakarta Timur: PT. Bumi Aksara.

Zaini Hisyam, dkk. (2010). Strategi Pembelajaran Aktif. Jakarta: Depdiknas. 